\title{
Characteristics of Particulate Matter Emitted from a Coal-Fired Power Plant
}

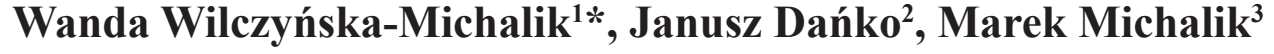 \\ 'Institute of Geography, Pedagogical University of Cracow, Kraków, Poland \\ ${ }^{2}$ PGE Energia Ciepła Oddział nr 1, Kraków, Poland \\ ${ }^{3}$ Institute of Geological Sciences, Jagiellonian University, Kraków, Poland
}

Received: 7 January 2019

Accepted: 28 March 2019

\begin{abstract}
Particulate matter (PM) emitted into the atmosphere from a hard coal-fired power plant equipped with a pulverised fuel boiler was studied using X-ray diffractometry (XRD), inductively coupled plasma mass spectrometry (ICP-MS), and scanning electron microscopy fitted with X-ray energy-dispersive spectrometry (SEM-EDS). The PM emitted from coal-fired power plants is rarely studied, in contrast to fly ash collected during flue gas cleaning.

The material of PM is composed of particles differing in size, morphology, and chemical composition. Aluminosilicate spherical particles dominate, but other particles also occur (irregular aluminosilicate particles, char particles, irregular particles of quartz, Fe oxides, particles rich in $\mathrm{Fe}, \mathrm{Cr}$ and $\mathrm{Ni}$, barite, and others). The size of other particles varies from $50 \mu \mathrm{m}$ to $250 \mu \mathrm{m}$. The emitted PM is strongly enriched in several elements in comparison to average coal ash or upper continental crust (e.g., $\mathrm{Ag}, \mathrm{Bi}, \mathrm{Cd}, \mathrm{Cr}, \mathrm{Hg}$, $\mathrm{Mo}, \mathrm{Ni}, \mathrm{Re}, \mathrm{Se}$, and $\mathrm{Zn}$ ). The content of bioavailable, water-soluble fraction (containing $\mathrm{S}, \mathrm{Ca}, \mathrm{K}, \mathrm{Na}, \mathrm{Cl}$ and subordinate $\mathrm{Zn}$ and $\mathrm{Ni}$ ) is ca $5 \%$.

The broad variation of the size and composition of the emitted PM indicates the potential environmental impact and possibility of dispersion over a large area.
\end{abstract}

Keywords: fly ash, coal-fired power plant, pulverised fuel boiler, particulate matter (PM), chemical composition of emitted particles

\section{Introduction}

Thermal power plants occupy 26 positions on the list of 30 industrial facilities in Europe causing the highest damage costs because of emissions of pollutants into the air during the period from 2008 to 2012 [1]. It was estimated that 257 power plants in the EU caused

*e-mail: Wanda.wilczynska-michalik@up.krakow.pl
22900 premature deaths in 2013, with approximately $83 \%$ (ca 19000 ) of these deaths caused by $\mathrm{PM}_{2.5}$ (particulate matter [PM] characterised by an aerodynamic diameter below $2.5 \mu \mathrm{m}$ ) [2]. According to Vasev [3], the annual cost of air pollution emitted from coal-powered plants in Europe is significant: 18200 premature deaths, 2100000 days of medication required, 4100000 working days lost and a combined cost of $€ 15.5-42.8$ billion.

The problem of pollutant emissions from power plants is important, despite the accepted legal regulations. 
According to the US Environmental Protection Agency (EPA), the emission limit from coal-fired power plants is $20 \mathrm{mg} / \mathrm{Nm}^{3}$, while according to the EU the limit is $30 \mathrm{mg} / \mathrm{Nm}^{3}$ [4]. According to ultra-low-emission reform, which is now implemented in China, the emission level will be reduced to $5 \mathrm{mg} / \mathrm{Nm}^{3}$ [4]. Limits are related to so-called filterable PM, while the control of condensable PM emissions $[4,5]$ is more difficult.

According to statistical data [6], the amount of fly ash (PM) emitted into the atmosphere during coal burning processes in power plants in Poland has decreased systematically - from $362999 \mathrm{Mg}$ in 1995 to $27900 \mathrm{Mg}$ in 2015, but its contribution to air pollution is still significant. Vasev [3] reported data from the Polish National Centre for Emissions Balancing and Management (KOBIZE), indicating that coal power plants are responsible for $11 \%$ of primary PM (PM2.5), $51 \%$ of sulphur dioxide $\left(\mathrm{SO}_{2}\right)$ and $31 \%$ of nitrogen oxide (NOx) emissions in Poland. Coal is the dominant fuel in terms of energy production in Poland (hard coal: $59.0 \%$, lignite: $33.6 \%$ in 2011) [7]. It is assumed that in 2050 the share of coal in energy production in Poland will be around $50 \%$ [8].

The composition and properties of fly ash collected during the cleaning of flue gas in power plants are well studied because of the use of this material in numerous applications [9]. The PM emitted from power plants is subject to online monitoring (determining the total emissions of PM) and additional analyses according to legal regulations. Characteristics important for the evaluation of the range of dispersion of PM emitted from power plants into the atmosphere for identifying particles emitted from power plants in atmospheric PM samples or for determining environmental impact (e.g., the mobility of compounds), are less well known.

We present results from the analysis of PM emitted from a coal-fired power plant in Poland. Total PM emission from this power plant was ca $100 \mathrm{Mg}$ in 2014.

\section{Material and Methods}

Our sample was collected from a coal-fired power plant in Poland. Coal-biomass co-combustion wasn't applied in the boiler from which the sample was collected. Hard coal was supplied from the Upper Silesian Coal Basin in Poland. Because the total mass of the sample was around $1.5 \mathrm{~g}$, only basic analyses were possible.

The power plant was equipped with pulverised fuel boilers. The sample was collected from an OP-650k-type boiler. Electric power of the unit was 200 MW. Temperature of combustion was within the range 1100 to $1300^{\circ} \mathrm{C}$. The sample was collected after the electrostatic precipitator, from the automatic measurement system (AMS) in isokinetic condition. Concentration of fly ash was $30-100 \mathrm{mg} / \mathrm{Nm}^{3}$. The boiler was equipped with desulphurisation and denitrification systems.
Powder X-ray diffraction was used to determine the mineral composition of the ash. A Philips X'Pert APD diffractometer (PW3830 generator and PW3020 vertical goniometer) was used. The samples were irradiated by $\mathrm{CuK} \alpha$ radiation (voltage $40 \mathrm{kV}$, current $30 \mathrm{~mA}$ ) and the data were collected in the range $2-64^{\circ} 2 \Theta$, with a step of $0.02^{\circ} 2 \Theta$ and dwell time of $1 \mathrm{sec}$.

The morphology and chemical composition of the $\mathrm{PM}$ as well as the components of the dry residue after the evaporation of water solution obtained after washing the material were analysed using scanning electron microscopy with energy dispersive spectrometry (SEMEDS). A HITACHI S-4700 field emission microscope and NORAN spectrometer were used. The grainy preparations were coated with carbon or gold. Both secondary electrons and back-scattered electron signals were used for imaging. Quantitative determination of the chemical elements' content was based on the standardless method.

The content of selected major and trace elements was determined using the inductively coupled plasma mass spectrometry (ICP-MS) method (after modified Aqua Regia digestion) in the Bureau Veritas Laboratory (formerly Acme Laboratory, Vancouver, Canada). Additionally, the lead isotopic composition was determined $\left({ }^{207} \mathrm{~Pb} /{ }^{208} \mathrm{~Pb}\right.$ and $\left.{ }^{206} \mathrm{~Pb} /{ }^{207} \mathrm{~Pb}\right)$. The content of $\mathrm{Si}$ was evaluated based on the average $\mathrm{Si}: \mathrm{Al}$ ratio measured using the SEM-EDS method.

\section{Results and Discussion}

\section{Mineral Composition of Emitted PM}

Quartz and mullite were determined in the mineral composition of PM using the X-ray diffractometry (XRD) method. Significant elevation of the X-ray diffractogram background indicates high content of amorphous glassy material.

\section{Spherical Aluminosilicate Particles in the Emitted PM}

Spherical aluminosilicate particles are the main component of the PM (Fig. 1a). Their size varies within a broad range from below $1 \mu \mathrm{m}$ (Fig. 1b) to $40 \mu \mathrm{m}$ (Fig. 1c). Smaller particles dominate significantly, taking into account their number, but the share of larger particles in the mass of spherical particles is quite important. The presence of relatively large spherical particles in the studied material emitted from the power plant differentiates this material from the fly ash described by numerous authors [e.g., 10]. Significant variation of the emitted particles' size indicates that it is possible to expect their deposition over a broad area, where the largest could be deposited close to the emission source while the smallest particles could be transported over long distances. 

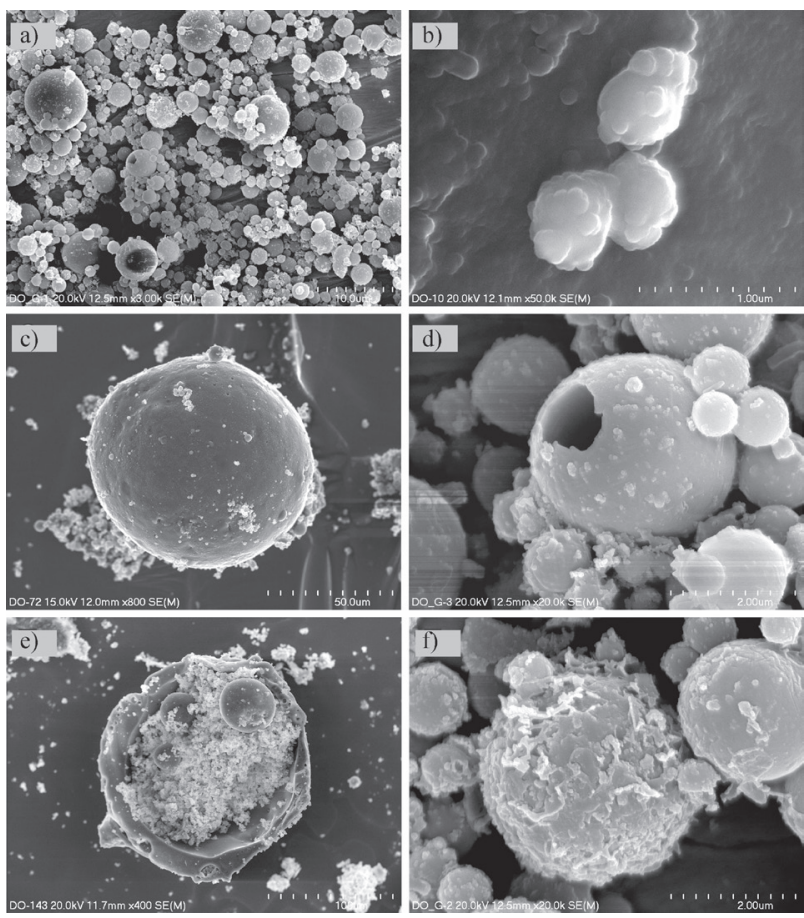

Fig. 1. a) Particulate matter dominated by aluminosilicate spherical particles (SEM image); b) small spherical particles $(<1 \mu \mathrm{m})$ with sulphate accumulation on the surface (SEM image); c) large spherical particle (SEM image); d) cenosphere in emitted PM (SEM image); e) plerosphere filled with spheres of various sizes (SEM image); f) encrustations of Ca-sulphate on spherical particles (SEM image).

Cenospheres (Fig. 1d) and plerospheres (Fig. 1e) occur in the emitted material ash, but it is difficult to estimate their content because only grainy preparations were studied. The very small amount of sample material excluded the possibility of preparing polished material suitable for the observation of sections of the particles.

The surface of the spherical particles is covered by encrustations dominated by Ca-sulphates (Fig. 1f). Sulphates occur in the form of irregular grains or as
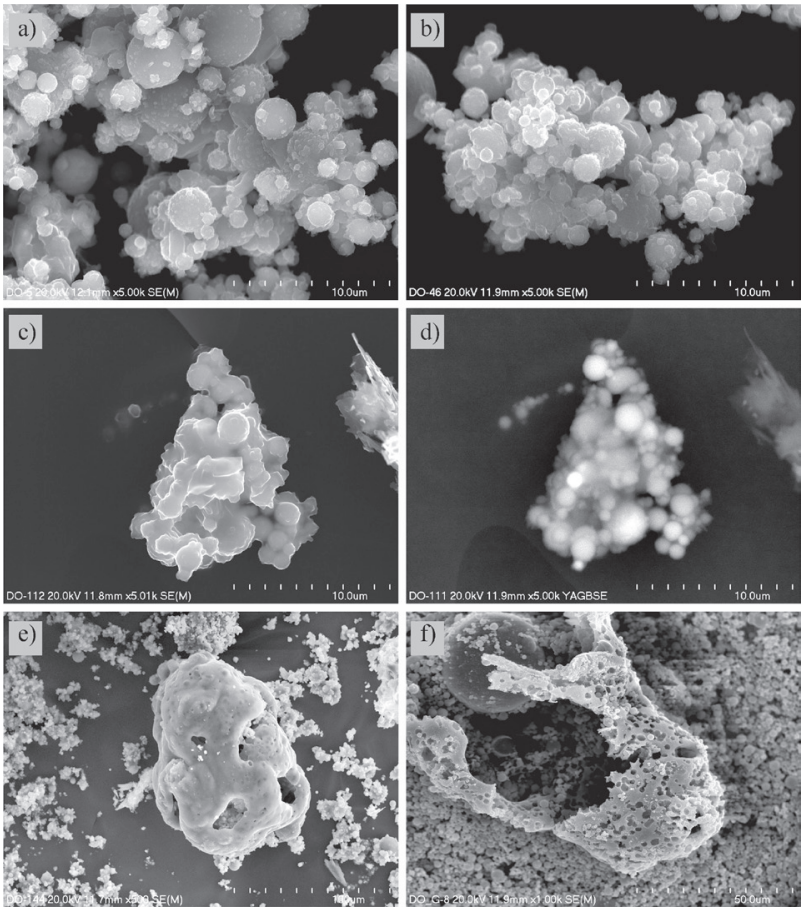

Fig. 2. a) Irregular and elongated sulphate crystals in spherical aluminosilicate particles aggregate (SEM image); b) Casulphates in spherical aluminosilicate particles aggregate (SEM image), secondary electron signal; c) Surface of spherical aluminosilicate particles aggregate covered by $\mathrm{Ca}$-sulphates (SEM image), secondary electrons image; d) the same aggregate (SEM image), backscattered electrons image with highly visible spherical particles, and brighter ones are enriched in $\mathrm{Fe}$; e) nonspherical aluminosilicate particle (SEM image); f) thin-walled char particle (SEM image).

elongated crystals (Fig. 2a-c). The sulphates often bind spherical grains in aggregates (Fig. 2a, b) and cover the surface of aggregates (Fig. 2c, d). Sulphates form during the condensation of vapour on spherical particles originating from break-up and coalescence [4]. Aggregates can also be formed due to the charging of particles in electrostatic precipitators [10].

Table 1. Chemical characteristics of spherical aluminosilicate particles (ratios of content of elements in wt\%).

\begin{tabular}{|c|c|c|c|c|}
\hline $\begin{array}{c}\text { Size fraction } \\
\text { Number of analyses }\end{array}$ & $\begin{array}{c}<1 \mu \mathrm{m} \\
21\end{array}$ & $\begin{array}{c}1-2.5 \mu \mathrm{m} \\
45\end{array}$ & $\begin{array}{c}2.5-10 \mu \mathrm{m} \\
16\end{array}$ & $\begin{array}{c}>10 \mu \mathrm{m} \\
10\end{array}$ \\
\hline $\begin{array}{c}\mathrm{Si} / \mathrm{Al} \text { (average) } \\
\mathrm{Si} / \mathrm{Al} \text { (range of variation) }\end{array}$ & $\begin{array}{c}1.61 \\
0.92-4.29\end{array}$ & $\begin{array}{c}1.59 \\
0.77-8.00\end{array}$ & $\begin{array}{c}1.95 \\
0.70-5.12\end{array}$ & $\begin{array}{c}1.84 \\
1.09-2.43\end{array}$ \\
\hline $\begin{array}{c}\mathrm{P} / \mathrm{Si} \text { (average) } \\
\mathrm{P} / \mathrm{Si} \text { (range of variation) }\end{array}$ & $\begin{array}{c}0.22 \\
0.00-2.14\end{array}$ & $\begin{array}{c}0.22 \\
0.00-5.69\end{array}$ & $\begin{array}{c}0.31 \\
0.00-4.93\end{array}$ & $\begin{array}{c}0.01 \\
0.00-0.05\end{array}$ \\
\hline $\begin{array}{c}\mathrm{K} / \mathrm{Si} \text { (average) } \\
\mathrm{K} / \mathrm{Si} \text { (range of variation) }\end{array}$ & $\begin{array}{c}0.12 \\
0.00-0.23\end{array}$ & $\begin{array}{c}0.14 \\
0.00-0.34\end{array}$ & $\begin{array}{c}0.16 \\
0.00-0.29\end{array}$ & $\begin{array}{c}0.08 \\
0.02-0.18\end{array}$ \\
\hline $\begin{array}{c}\mathrm{Ca} / \mathrm{Si} \text { (average) } \\
\mathrm{Ca} / \mathrm{Si} \text { (range of variation) }\end{array}$ & $\begin{array}{c}0.41 \\
0.05-3.61\end{array}$ & $\begin{array}{c}0.42 \\
0.00-9.32\end{array}$ & $\begin{array}{c}0.55 \\
0.00-7.16\end{array}$ & $\begin{array}{c}0.28 \\
0.00-0.51\end{array}$ \\
\hline $\begin{array}{c}\mathrm{Mg} / \mathrm{Si} \text { (average) } \\
\mathrm{Mg} / \mathrm{Si} \text { (range of variation) }\end{array}$ & $\begin{array}{c}0.08 \\
0.00-0.34\end{array}$ & $\begin{array}{c}0.12 \\
0.00-1.90\end{array}$ & $\begin{array}{c}0.38 \\
0.00-5.27\end{array}$ & $\begin{array}{c}0.11 \\
0.04-0.17\end{array}$ \\
\hline $\begin{array}{c}\mathrm{Fe} / \mathrm{Si} \text { (average) } \\
\mathrm{Fe} / \mathrm{Si} \text { (range of variation) }\end{array}$ & $\begin{array}{c}0.25 \\
0.05-0.60\end{array}$ & $\begin{array}{c}0.37 \\
0.04-3.28\end{array}$ & $\begin{array}{c}0.24 \\
0.02-1.19\end{array}$ & $\begin{array}{c}0.53 \\
0.13-1.05\end{array}$ \\
\hline
\end{tabular}


A dominant part of the spherical particles is composed of aluminosilicate material. The ratios of dominant elements in the individual particles vary within a broad range, while it is difficult to notice any systematic variation of the chemical composition of the spherical particles in relation to their size (Table 1). Inter-elemental variation (i.e., the content of elements recalculated to an oxygen-free basis) diagrams indicate some regularities. It is possible to notice a decrease in the content of $\mathrm{Ca}$ and $\mathrm{Mg}$, with increasing content of $\mathrm{Si}$ (Fig. 3a, b). The content of $\mathrm{K}$ elevates with the increasing content of Si (Fig. 3c). The relationships between the content of $\mathrm{Na}$ and $\mathrm{Si}$ are irregular (Fig. 3d).

Most of the aluminosilicate particles contain $\mathrm{P}$, where the content of $\mathrm{P}$ is generally below $5 \mathrm{wt} \%$. A limited number of particles contain more $\mathrm{P}$ - from $5 \mathrm{wt} \%$ to over $25 \mathrm{wt} \%$. For spheres with content of $\mathrm{P}$ above $5 \mathrm{wt} \%$ and $\mathrm{Ca}$ above $10 \mathrm{wt} \%$, it is possible to notice a visible positive correlation between the $\mathrm{Ca}$ and $\mathrm{P}$ content (Fig. 3e). A similar correlation was found by Weinberger et al. [11] for the bulk chemical composition of fly ash from different power plants. It is possible to notice that most of the particles with content of $\mathrm{P}$ above
$5 \mathrm{wt} \%$ are characterised by a total content of $\mathrm{Si}$ and $\mathrm{Al}$ below $40 \mathrm{wt} \%$ (Fig. 3f).

The content of $\mathrm{Fe}$ (recalculated to an oxygen-free basis) is usually below $10 \mathrm{wt} \%$. Spheres with Fe content from $20 \mathrm{wt} \%$ to above $50 \mathrm{wt} \%$ were also noted. It is most likely that the high content of Fe is related to the presence of intergrowths of $\mathrm{Fe}$ oxides or metallic $\mathrm{Fe}$ with aluminosilicate glass.

Other elements present in some of the aluminosilicate spheres are $\mathrm{Zn}$ (up to $1.5 \mathrm{wt} \%$ ), $\mathrm{Cr}$ (up to $0.6 \mathrm{wt} \%$ ), $\mathrm{Mn}$ (up to $1.4 \mathrm{wt} \%$ ), and $\mathrm{Ba}$ (up to $5.9 \mathrm{wt} \%$ ).

\section{Non-Spherical Aluminosilicate Particles}

The frequency of occurrence of irregular (usually close to oval) aluminosilicate particles is low, but they are relatively large (from ca $50 \mu \mathrm{m}$ to more than $100 \mu \mathrm{m}$; Fig. 2e). Usually, it is possible to notice hollows on their smooth surface. Small spherical particles are often present in hollows or attached to the surface. The chemical composition of these particles is dominated by $\mathrm{Si}$ and $\mathrm{Al}$, with lower content of $\mathrm{Ca}, \mathrm{K}$, and $\mathrm{Fe}$. Generally, their chemical composition is similar to the spherical particles. a)

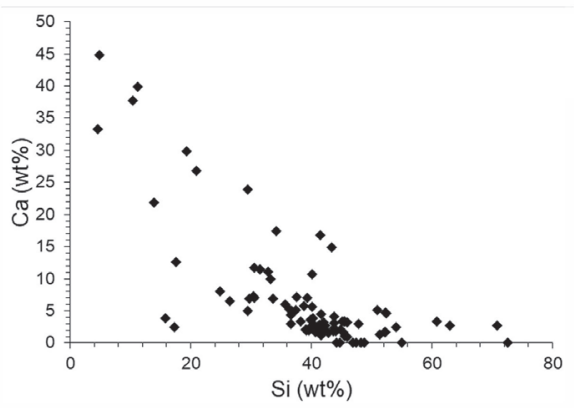

c)
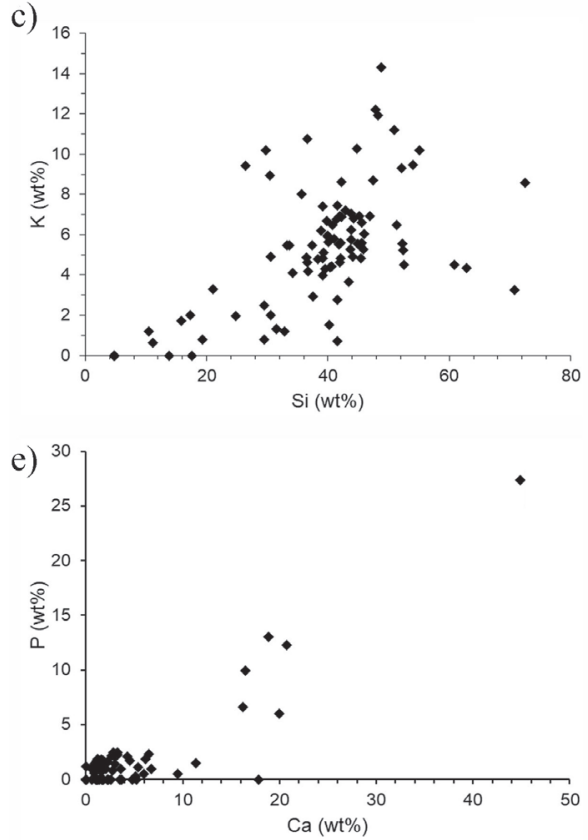

b)
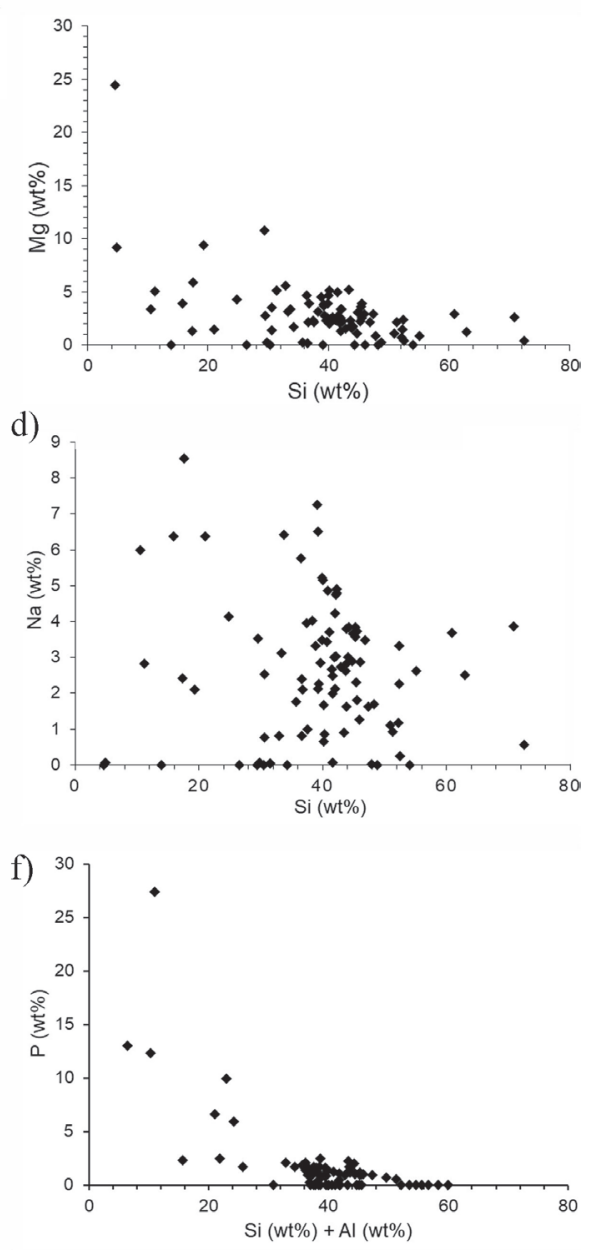

Fig. 3. Diagrams of inter-elemental variation. 

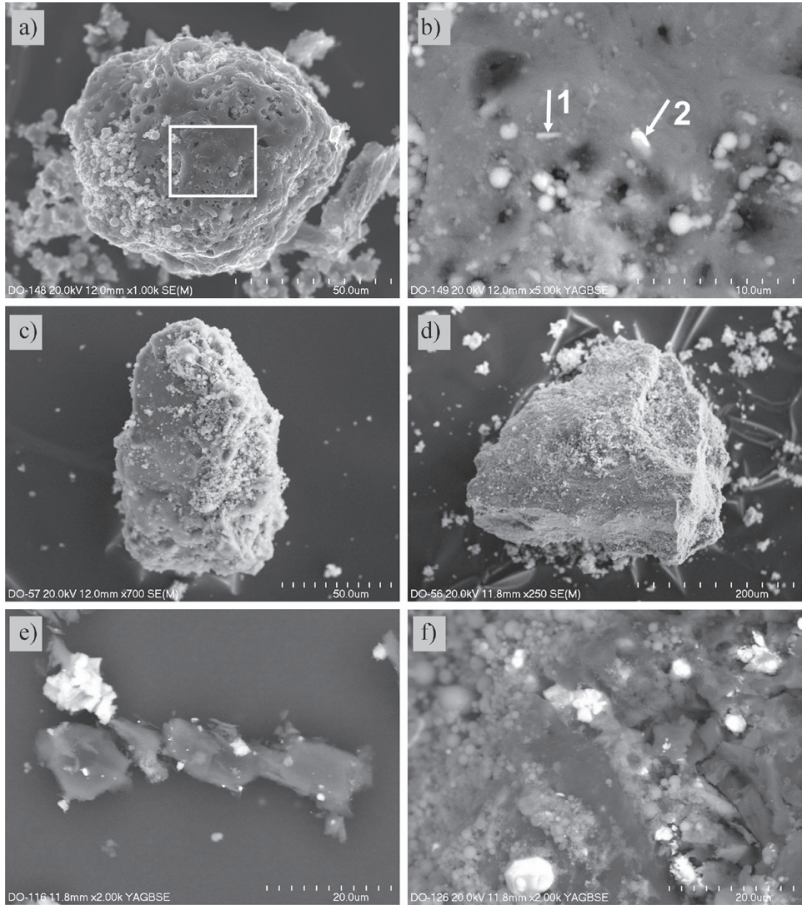

Fig. 4. a) Dense char particle with white rectangle - enlarged area presented on Fig. 4b (SEM image), secondary electrons signal; b) enlarged area from Fig. 4a, with domains enriched with $\mathrm{Fe}$ and $\mathrm{Cr}$ (arrow 1) or $\mathrm{Ti}$ (arrow 2) inside the char particle (SEM image), and backscattered electrons signal; c) irregular quartz paricle with numerous spherical particles (SEM image); d) irregular Fe-oxide particle with numerous spherical particles (SEM image); e) Fe, Cr and Ni rich bright particles (SEM image) and backscattered electrons signal; f) bright barite particles (SEM image), backscattered electrons signal.

\section{Char Particles}

Char particles are common in the material emitted from the power plant, with the size varying from ca $50 \mu \mathrm{m}$ to more than $100 \mu \mathrm{m}$ (Fig. 2f, 4a). Char represent unburned carbon particles formed during pyrolysis [12]. The unburned carbon content is a measure of the burning efficiency, but also determines the application of fly ash. The variation of the char particles' morphology in the studied material is broad. The particles represent all groups described by numerous authors, namely the group I type (thin-walled with high porosity), the group II type (thick-walled with medium porosity) and the group III type (dense with low porosity) [e.g., 13]. In numerous pores in the char, small aluminosilicate spherical particles can be observed. Other aluminosilicate forms rarely occur. The form of occurrence of aluminosilicate matter can likely be related to the form of occurrence of mineral matter in coal [14]. Using SEM back-scattered images (BSE), it is possible to notice the occurrence of elongated domains enriched with $\mathrm{Fe}$ (along with $\mathrm{Cr}$ ) or Ti inside the char particles (Fig. 4a, b). The possibilities for the identification of metal-rich particles in char using SEM are limited. Chen et al. [15] described numerous $\mathrm{Ti}$ and $\mathrm{Al}$ particles of different sizes in char matrix in coal fly ash using energy-filtered transmission electron microscopy (TEM).

Char particles emitted from a power plant and dispersed in the environment can influence soil properties. Biochar improves soil fertility, carbon sequestration, the immobilisation of toxic elements, the increase of $\mathrm{pH}$, and the increase of water sorption, and could facilitate a higher incidence of plant disease [16, 17].

\section{Other Particles in Emitted PM}

Relatively large, irregular-in-shape particles in the emitted material are represented by quartz (Fig. 4c) and Fe oxides (Fig. 4d). The particles can reach $250 \mu \mathrm{m}$ in size, but their diameter tends to be between $50 \mu \mathrm{m}$ and $100 \mu \mathrm{m}$.

Although the number of analyses is relatively low, it is possible to distinguish two types of particles containing significant amounts of $\mathrm{Fe}, \mathrm{Cr}$ and $\mathrm{Ni}$. The larger particles contain lower amounts of $\mathrm{Cr}$ and $\mathrm{Ni}$ compared with the smaller ones (Fig. 4e; Table 2). Particles containing more than $50 \mathrm{wt} \%$ of $\mathrm{Fe}$ and approximately $20 \mathrm{wt} \%$ of $\mathrm{Cr}$ with minor amount of $\mathrm{Ni}(\mathrm{ca} 6 \mathrm{wt} \%)$ and sometimes low content of $\mathrm{Mn}$ are usually irregular (Table 2). $\mathrm{Fe}, \mathrm{Cr}$ and Ni occur in coal in different forms, but it is also possible to assume that these metals are derived from stainless steel from various installations in the power plant [18]. The co-occurrence of these metals in the studied particles supports the assumption that stainless steel is the dominant source of these particles. The toxicity of $\mathrm{Cr}$ is strongly related to the oxidation state [18], although the oxidation state of $\mathrm{Cr}$ in the studied particles is unknown. Generally, the emission of $\mathrm{Cr}(\mathrm{VI})$ from coalfired power plants is high. Świetlik et al. [19] reported that the total annual emission of $\mathrm{Cr}(\mathrm{VI})$ in Poland is equal to $60 \mathrm{Mg}$. The $\mathrm{Cr}(\mathrm{VI})$ level in fly ash from pulverised fuel boilers is higher compared with other boilers, e.g., fluidised bed boiler and stoker-fired boilers. According to Jiao et al. [20], the oxidation of $\mathrm{Cr}$ (III) to $\mathrm{Cr}(\mathrm{VI})$ is most effective at temperatures of $800^{\circ} \mathrm{C}$ at oxygen-containing sites at the coal matrix.

The oxidation state of $\mathrm{Cr}$ in atmospheric PM may change in relation to different factors [21, 22]. The form of occurrence of $\mathrm{Ni}$ is also unknown, but it is possible to notice that it is relatively soluble (see the "Chemical composition of emitted PM" section).

The emitted material also contains numerous smaller particles of various chemical composition. The dominant group is rich in $\mathrm{Si}$ and $\mathrm{Al}$, and represents the product of thermal transformation of common aluminosilicate minerals (e.g., clay minerals and feldspars). Barite occurs as small particles of variable size (Fig. 4f). Fine particles (or nanoparticles) of barite noted in aerosol samples are connected with coal combustion [23], but other sources are also possible, such as barite from the brake pads used in motor vehicles [24]. A unique particle rich in $\mathrm{Au}$ (above $98 \mathrm{wt} \%$ ) ca $2 \mu \mathrm{m}$ in diameter was noted. 
Table 2. Chemical composition of irregular particles containing $\mathrm{Fe}, \mathrm{Cr}$, and $\mathrm{Ni}$ (wt\%).

\begin{tabular}{|c|c|c|c|c|c|c|c|c|c|c|c|}
\hline Analysis No. & $80(1)$ & $103(1)$ & 109(1) & 113(1) & $113(2)$ & $113(3)$ & $116(4)$ & $116(3)$ & $118(1)$ & $118(2)$ & $116(1)$ \\
\hline $\mathrm{Fe}$ & 50.77 & 65.83 & 53.65 & 50.47 & 67.16 & 38.71 & 64.03 & 49.73 & 47.75 & 42.14 & 51.15 \\
\hline $\mathrm{Cr}$ & 6.32 & 7.90 & 17.13 & 21.99 & 15.15 & 35.04 & 11.70 & 15.91 & 18.91 & 24.38 & 39.70 \\
\hline $\mathrm{Ni}$ & 1.16 & 1.46 & 5.68 & 6.84 & 5.28 & 1.80 & 7.36 & 7.34 & 5.14 & 8.30 & 2.77 \\
\hline $\mathrm{Mn}$ & --- & --- & 4.63 & --- & 1.48 & 3.08 & 1.50 & 1.70 & 1.40 & 0.85 & --- \\
\hline $\mathrm{Ti}$ & 1.16 & --- & --- & --- & --- & --- & --- & --- & --- & --- & --- \\
\hline V & --- & --- & --- & --- & --- & --- & --- & --- & --- & --- & 0.29 \\
\hline $\mathrm{Si}$ & 12.89 & 0.73 & 0.69 & 0.52 & 0.68 & 1.53 & 0.57 & 1.34 & 0.92 & 1.07 & 3.11 \\
\hline $\mathrm{Al}$ & 8.60 & 1.15 & 1.54 & 0.59 & 0.58 & 0.66 & 0.51 & 1.56 & 0.79 & 0.56 & 1.80 \\
\hline $\mathrm{P}$ & 0.81 & --- & --- & --- & --- & --- & --- & --- & --- & --- & --- \\
\hline $\mathrm{Ca}$ & 3.10 & 1.07 & --- & --- & --- & 0.34 & --- & --- & 0.87 & --- & 1.18 \\
\hline $\mathrm{Mg}$ & 0.66 & --- & --- & --- & --- & --- & --- & --- & --- & --- & --- \\
\hline K & 1.51 & --- & 0.66 & 0.32 & 1.04 & 3.73 & 0.19 & 1.87 & 1.96 & 3.37 & --- \\
\hline $\mathrm{Na}$ & --- & --- & --- & --- & --- & 0.82 & --- & 1.33 & 1.36 & 2.37 & --- \\
\hline $\mathrm{S}$ & 0.62 & 2.04 & 4.25 & 0.68 & 0.48 & 2.90 & 0.52 & 0.89 & 0.46 & 0.63 & --- \\
\hline $\mathrm{Cl}$ & 2.35 & 6.01 & 1.68 & 9.72 & 0.53 & 5.42 & 6.51 & 0.64 & 1.66 & 1.42 & --- \\
\hline $\mathrm{O}$ & 10.04 & 13.39 & 10.08 & 8.86 & 7.60 & 5.96 & 7.12 & 17.69 & 18.77 & 14.92 & --- \\
\hline & ca $250 \mu \mathrm{m}$ & ca $100 \mu \mathrm{m}$ & $<10 \mu \mathrm{m}$ & $<10 \mu \mathrm{m}$ & $<10 \mu \mathrm{m}$ & $<10 \mu \mathrm{m}$ & $<10 \mu \mathrm{m}$ & $<5 \mu \mathrm{m}$ & $<5 \mu \mathrm{m}$ & $<5 \mu \mathrm{m}$ & $<1 \mu \mathrm{m}$ \\
\hline
\end{tabular}

\section{Chemical Composition of Emitted PM}

The chemical composition of the sample is presented in Table 3. The material is characterised by the relatively high content of iron $(>5 \mathrm{wt} \%)$. Also, the content of several trace elements is high $(\mathrm{Cr}, \mathrm{Ba}, \mathrm{Ni}, \mathrm{Cu}$, $\mathrm{Hg}$; Table 3). The concentration of numerous elements (As, Ba, $\mathrm{Co}, \mathrm{Cu}, \mathrm{Mo}, \mathrm{Ni}, \mathrm{Pb}, \mathrm{Sn}, \mathrm{Zn}$ ) in the emitted material is higher than accepted in soil and ground used for agriculture [25]. Comparison of the chemical composition of the studied material with average ash from hard coal indicates that numerous elements are significantly enriched in the studied PM (Table 4). The degree of enrichment is not related to the boiling or melting temperatures of elements, which is a typical result of fractionation between bottom and fly ash [26]. The concentration of different elements in ash is often related to the size of the ash particles. In the studied material, strong variation in the size and composition of the ash particles was noted, which could reduce the regularities of relationships. Different factors govern the chemical composition of fly ash; for example, the chemical composition and content of trace elements in coal, the forms of occurrence of elements in coal (in organic or mineral matter), the conditions of combustion, the probability of melting of mineral matter related to the temperature of combustion and mineral matter composition, the temperature of the fly ash collection, and the temperature of flue gases' outlet. According to Goodarzi and Sanei [27], the emitted quantity of elements in particles as compared to feed-coal is low ( $\mathrm{Zn}-1.35 \%$; $\mathrm{Ni}-0.55 \%$; As $-0.29 \%$; $\mathrm{Cr}-0.14 \%$; $\mathrm{V}-0.09 \%$; $\mathrm{Cd}-0.07 \%$; $\mathrm{Pb}-0.06 \%$; $\mathrm{Mo}-0.04 \%$; $\mathrm{Cu}-0.02 \%)$. The highest factors of enrichment were noted for $\mathrm{Ag}$ and $\mathrm{Cr}$ ( $>800$ and $>25$, respectively; Table 4). The content of $\mathrm{Cr}$ is relatively high, but the oxidation state is unknown. The content of numerous elements in the emitted material is similar to those noted in fly ash collected in flue gas cleaning systems in numerous European coal-fired power plants, except for $\mathrm{Cr}, \mathrm{Cu}, \mathrm{Hg}, \mathrm{Mo}, \mathrm{Ni}$, and $\mathrm{Zn}$, where the content is higher [28]. The content of $\mathrm{Hg}$ is within the range commonly reported for other power plants [29]. The measured contents of $\mathrm{Cd}, \mathrm{Co}, \mathrm{Cr}, \mathrm{Mn}, \mathrm{Ni}, \mathrm{Pb}, \mathrm{Sb}$, and $\mathrm{Se}$ in the emitted PM correspond to the values presented by Komosiński et al. [30] for emitted material from Polish power plants.

The relatively high content of $\mathrm{P}$ in the studied PM indicates that its emission into the atmosphere could induce significant environmental impact by the supply of a nutrient. Coal combustion is often considered to be a major source of atmospheric $\mathrm{P}$ in industrialised regions [11].

REE content in the analysed emitted material is low compared with coal fly ash collected in air pollution control installations [31-33].

The annual emission of total dust from the power plant was ca $100 \mathrm{Mg}$ in 2014. Taking into account 
Table 3. Chemical components in ash emitted from the power plant.

\begin{tabular}{|c|c|c|c|c|c|}
\hline Element & Unit & $\begin{array}{l}\text { Concen- } \\
\text { tration }\end{array}$ & Element & Unit & $\begin{array}{c}\text { Concen- } \\
\text { tration }\end{array}$ \\
\hline $\begin{array}{l}\text { Major } \\
\text { elements }\end{array}$ & & & $\mathrm{Pt}$ & $\mathrm{ppb}$ & 5 \\
\hline $\mathrm{Si}$ & $\mathrm{wt} \%$ & 7.17 & $\mathrm{Rb}$ & ppm & 71.5 \\
\hline $\mathrm{Al}$ & $\mathrm{wt} \%$ & 4.67 & $\mathrm{Re}$ & $\mathrm{ppb}$ & 94 \\
\hline $\mathrm{Ti}$ & wt $\%$ & 0.15 & $\mathrm{Sb}$ & $\mathrm{ppm}$ & 17.42 \\
\hline $\mathrm{Fe}$ & wt $\%$ & 5.13 & $\mathrm{Se}$ & ppm & $>100$ \\
\hline $\mathrm{Ca}$ & $\mathrm{wt} \%$ & 2.46 & $\mathrm{Sn}$ & $\mathrm{ppm}$ & 34.3 \\
\hline $\mathrm{Mg}$ & $\mathrm{wt} \%$ & 1.00 & $\mathrm{Sr}$ & $\mathrm{ppm}$ & 694.9 \\
\hline $\mathrm{Na}$ & $\mathrm{wt} \%$ & 0.53 & $\mathrm{Ta}$ & $\mathrm{ppm}$ & $<0.05$ \\
\hline $\mathrm{K}$ & $\mathrm{wt} \%$ & 1.22 & $\mathrm{Te}$ & $\mathrm{ppm}$ & 0.45 \\
\hline $\mathrm{S}$ & $\mathrm{wt} \%$ & 2.53 & $\mathrm{Th}$ & $\mathrm{ppm}$ & 12.7 \\
\hline $\mathrm{P}$ & $\mathrm{wt} \%$ & 0.65 & $\mathrm{Tl}$ & $\mathrm{ppm}$ & 5.95 \\
\hline $\begin{array}{c}\text { Trace } \\
\text { elements }\end{array}$ & & & $\mathrm{U}$ & $\mathrm{ppm}$ & 12.2 \\
\hline $\mathrm{Ag}$ & $\mathrm{ppb}$ & 516 & $\mathrm{~V}$ & $\mathrm{ppm}$ & 279 \\
\hline As & $\mathrm{ppm}$ & 49.1 & $\mathrm{~W}$ & $\mathrm{ppm}$ & 19.69 \\
\hline $\mathrm{Au}$ & $\mathrm{ppb}$ & 1.3 & W & $\mathrm{ppm}$ & 19.69 \\
\hline B & $\mathrm{ppm}$ & 192 & $\mathrm{Zn}$ & $\mathrm{ppm}$ & 1439 \\
\hline $\mathrm{Ba}$ & $\mathrm{ppm}$ & 1164 & $\mathrm{Zr}$ & $\mathrm{ppm}$ & 35.3 \\
\hline $\mathrm{Be}$ & $\mathrm{ppm}$ & 7.2 & & & \\
\hline $\mathrm{Bi}$ & $\mathrm{ppm}$ & 7.24 & REE & & \\
\hline $\mathrm{Cd}$ & $\mathrm{ppm}$ & 3.47 & $\mathrm{Sc}$ & ppm & 14.3 \\
\hline $\mathrm{Co}$ & $\mathrm{ppm}$ & 46.5 & $\mathrm{Y}$ & ppm & 31.65 \\
\hline $\mathrm{Cr}$ & $\mathrm{ppm}$ & 3108 & $\mathrm{La}$ & $\mathrm{ppm}$ & 37.2 \\
\hline $\mathrm{Cs}$ & $\mathrm{ppm}$ & 9.78 & $\mathrm{Ce}$ & $\mathrm{ppm}$ & 72.1 \\
\hline $\mathrm{Cu}$ & $\mathrm{ppm}$ & 458.5 & $\operatorname{Pr}$ & $\mathrm{ppm}$ & 9.5 \\
\hline $\mathrm{Ga}$ & $\mathrm{ppm}$ & 85.1 & $\mathrm{Nd}$ & $\mathrm{ppm}$ & 36.9 \\
\hline $\mathrm{Ge}$ & $\mathrm{ppm}$ & 3.4 & $\mathrm{Sm}$ & $\mathrm{ppm}$ & 7.2 \\
\hline $\mathrm{Hf}$ & $\mathrm{ppm}$ & 0.85 & $\mathrm{Eu}$ & $\mathrm{ppm}$ & 1.58 \\
\hline $\mathrm{Hg}$ & $\mathrm{ppb}$ & 1292 & $\mathrm{Gd}$ & $\mathrm{ppm}$ & 6.09 \\
\hline In & ppm & 0.51 & $\mathrm{~Tb}$ & $\mathrm{ppm}$ & 1.02 \\
\hline $\mathrm{Li}$ & $\mathrm{ppm}$ & 114.4 & Dy & $\mathrm{ppm}$ & 5.62 \\
\hline $\mathrm{Mn}$ & $\mathrm{ppm}$ & 752 & Ho & ppm & 0.92 \\
\hline Mo & ppm & 58 & Er & ppm & 3.13 \\
\hline $\mathrm{Nb}$ & ppm & 3.03 & $\mathrm{Tm}$ & $\mathrm{ppm}$ & 0.45 \\
\hline $\mathrm{Ni}$ & $\mathrm{ppm}$ & 938.9 & $\mathrm{Yb}$ & $\mathrm{ppm}$ & 2.72 \\
\hline $\mathrm{Pb}$ & $\mathrm{ppm}$ & 262 & $\mathrm{Lu}$ & $\mathrm{ppm}$ & 0.46 \\
\hline $\mathrm{Pd}$ & $\mathrm{ppb}$ & $<10$ & $\Sigma$ REE & $\mathrm{ppm}$ & 230.84 \\
\hline
\end{tabular}

the chemical composition of the material (Table 3), it is possible to calculate the approximate amounts of elements (in $\mathrm{kg}$ ) in the annual emission of PM from the power plant: $\mathrm{Fe}-5130 ; \mathrm{Cr}-310 ; \mathrm{Zn}-143$; $\mathrm{Ba}-116$; $\mathrm{Ni}$ - 93; $\mathrm{Sr}-69 ; \mathrm{Cu}-45 ; \mathrm{Pb}-26$; $\mathrm{Mo}-5.8 ; \mathrm{As}-4.9$; $\mathrm{Hg}-0.13$.

Comparison of the chemical composition of the emitted PM with Clarke values of coal ash [34] indicates strong enrichment in several elements (Table 4): Ag (enrichment factor $(\mathrm{EF})>800), \mathrm{Cr}(\mathrm{EF}>25), \mathrm{Ni}(\mathrm{EF}>9)$, $\mathrm{Zn}(\mathrm{EF}>8)$, and $\mathrm{Cu}, \mathrm{Mo}, \mathrm{Pb}, \mathrm{As}(\mathrm{EF}>4)$. Comparison with upper continental crust composition [35] indicates higher values of $\mathrm{EF}$ for numerous elements (e.g., $\mathrm{Se}-\mathrm{EF}>1100 ; \mathrm{Re}-\mathrm{EF}>470 ; \mathrm{Mo}-\mathrm{EF}>50 ; \mathrm{Sb}, \mathrm{Bi}-$ $\mathrm{EF}>40 ; \mathrm{Cd}-\mathrm{EF}>38 ; \mathrm{Cr}-\mathrm{EF}>33 ; \mathrm{Hg}-\mathrm{EF}>25)$. It is possible to assume that the prolonged deposition of PM emitted from coal-fired power plants can modify the chemical composition of soils.

$\mathrm{The} \mathrm{Pb}$ isotopic ratios of the emitted material are as follows: ${ }^{207} \mathrm{~Pb} / 208 \mathrm{~Pb}=0.413$ and ${ }^{206} \mathrm{~Pb} /{ }^{207} \mathrm{~Pb}=1.193$. The value of ${ }^{206} \mathrm{~Pb} /{ }^{207} \mathrm{~Pb}$ is similar to that noted in agricultural soils in Poland (and Central Europe), but the value of ${ }^{207} \mathrm{~Pb} /{ }^{208} \mathrm{~Pb}$ is significantly higher than the value for most of the European territory [36].

\section{Size Variation of Emitted Particles}

The distribution of the size of particles varies within a broad range. Spherical particles, usually aluminosilicate, dominate in the fraction below $1 \mu \mathrm{m}$. The particles are often encrusted with sulphate material. Spherical aluminosilicate or phosphate-rich particles vary in size from below $1 \mu \mathrm{m}$ to $40 \mu \mathrm{m}$. The size of non-spherical aluminosilicate particles is larger (from $50 \mu \mathrm{m}$ to $100 \mu \mathrm{m})$. Other particles, often up to $250 \mu \mathrm{m}$, vary both in size and composition (quartz, Fe oxides, clay minerals, and other metal-rich particles). The size of char particles is from $50 \mu \mathrm{m}$ to $100 \mu \mathrm{m}$. Taking into account the variation in size of the emitted particles, it is possible to expect that some of them will be deposited close to the emission source by sedimentation, while others can be transported over broad distances. Settling velocity also depends on particle shape and density. All these factors are important in modelling the range of transport of emitted material. Different environmental impacts can be caused by particles of different sizes. Large particles in the lower atmosphere may have a warming effect because of the absorption of reflected, long-wave radiation, whereas small particles may have a cooling effect by reflecting short-wave incoming radiation $[37,38]$.

\section{Water-Soluble Components in Emitted PM}

Water-soluble components constitute ca $5 \mathrm{wt} \%$ of the sample. It was possible to notice that after reaction with water, the surfaces of the spheres became smoother because of the dissolution of encrustations. 
Table 4. Enrichment factors: $\mathrm{EF} 1=\mathrm{C}_{\mathrm{XFA}} / \mathrm{C}_{\mathrm{XCAClarke}}\left(\mathrm{C}_{\mathrm{XFA}}\right.$ - concentration of element $\mathrm{X}$ in emitted fly ash and $\mathrm{C}_{\mathrm{XCAClarke}}$ - concentration of element $\mathrm{X}$ in coal ash Clarke after [34] and $\mathrm{EF} 2=\mathrm{C}_{\mathrm{XFA}} / \mathrm{C}_{\mathrm{XUpper} \mathrm{crust}}\left(\mathrm{C}_{\mathrm{XFA}}\right.$ - concentration of element $\mathrm{X}$ in emitted fly ash and $\mathrm{C}_{\mathrm{XUpper} \text { crust }}-$ concentration of element $\mathrm{X}$ in upper crust after [35]); values higher than 2.0 indicated in bold.

\begin{tabular}{|c|c|c|c|c|c|}
\hline Element & $\begin{array}{c}\mathrm{EF} 1=\mathrm{C}_{\mathrm{XFA}}{ }^{\prime} \\
\mathrm{C}_{\mathrm{XCAClarke}}\end{array}$ & $\begin{array}{c}\mathrm{EF} 2=\mathrm{C}_{\mathrm{XFA}} / \\
\mathrm{C}_{\mathrm{XUpper} \mathrm{crust}}\end{array}$ & Element & $\begin{array}{c}\mathrm{EF} 1=\mathrm{C}_{\mathrm{XFA}} / \\
\mathrm{C}_{\mathrm{XCAClarke}}\end{array}$ & $\begin{array}{c}\mathrm{EF} 2=\mathrm{C}_{\mathrm{XFA}}{ }^{\prime} \\
\mathrm{C}_{\mathrm{XUpper} \mathrm{crust}}\end{array}$ \\
\hline $\mathrm{Ag}$ & 819.05 & 9.74 & $\mathrm{Se}$ & & $>1100$ \\
\hline As & 1.14 & 10.23 & $\mathrm{Sn}$ & 4.29 & 16.33 \\
\hline $\mathrm{Au}$ & 0.05 & 0.87 & $\mathrm{Sr}$ & 0.95 & 2.17 \\
\hline B & 0.74 & 11.29 & Th & 0.55 & 1.21 \\
\hline $\mathrm{Ba}$ & 1.19 & 1.87 & $\mathrm{Tl}$ & 1.29 & 6.61 \\
\hline $\mathrm{Be}$ & 0.60 & 3.43 & U & 0.81 & 4.52 \\
\hline $\mathrm{Bi}$ & 0.97 & 45.25 & V & 1.64 & 2.88 \\
\hline $\mathrm{Cd}$ & 2.89 & 38.56 & W & 2.52 & 10.36 \\
\hline $\mathrm{Co}$ & 1.26 & 2.69 & Y & 0.56 & 1.51 \\
\hline $\mathrm{Cr}$ & 25.90 & 33.78 & $\mathrm{Zn}$ & 8.47 & 21.48 \\
\hline Cs & 1.22 & 2.00 & $\mathrm{Zr}$ & 0.15 & 0.18 \\
\hline $\mathrm{Cu}$ & 4.17 & 16.38 & & & \\
\hline $\mathrm{Ga}$ & 2.36 & 4.86 & $\mathrm{La}$ & 0.49 & 1.20 \\
\hline $\mathrm{Ge}$ & 0.19 & 2.43 & $\mathrm{Ce}$ & 0.52 & 1.14 \\
\hline $\mathrm{Hf}$ & 0.09 & 0.16 & $\operatorname{Pr}$ & 0.37 & 1.33 \\
\hline $\mathrm{Hg}$ & 1.49 & 25.84 & $\mathrm{Nd}$ & 0.49 & 1.37 \\
\hline In & & 9.11 & $\mathrm{Sm}$ & 0.51 & 1.53 \\
\hline $\mathrm{Li}$ & 1.40 & 5.44 & $\mathrm{Eu}$ & 0.61 & 1.58 \\
\hline Mo & 4.15 & 52.75 & $\mathrm{Gd}$ & 0.38 & 1.52 \\
\hline $\mathrm{Nb}$ & 0.14 & 0.25 & $\mathrm{~Tb}$ & 0.49 & 1.46 \\
\hline $\mathrm{Ni}$ & 9.39 & 19.98 & Dy & 0.37 & 1.44 \\
\hline $\mathrm{Pb}$ & 4.76 & 15.41 & Ho & 0.19 & 1.11 \\
\hline $\mathrm{Rb}$ & 0.65 & 0.85 & Er & 0.49 & 1.36 \\
\hline $\operatorname{Re}$ & & 474.75 & $\mathrm{Tm}$ & 0.20 & 1.50 \\
\hline $\mathrm{Sb}$ & 2.32 & 43.55 & $\mathrm{Yb}$ & 0.39 & 1.36 \\
\hline $\mathrm{Sc}$ & 0.60 & 1.02 & $\mathrm{Lu}$ & 0.35 & 1.48 \\
\hline
\end{tabular}

Dry residuum after evaporation of the solution was not studied in detail because of the very low sample amount. The chemical composition, determined using the SEM-EDS method, is dominated by sulphates of $\mathrm{Ca}, \mathrm{K}, \mathrm{Mg}$, and $\mathrm{Na}$. Low content of $\mathrm{Cl}$ was noticed. Our results do not support the presence of $\mathrm{Al}$ and $\mathrm{K}$, in addition to $\mathrm{S}$ in coatings, as reported by Fishman et al. [39]. In several analytical spots, $\mathrm{Zn}$ (up to $2.53 \mathrm{wt} \%$ ) and $\mathrm{Ni}$ (up to $2.24 \mathrm{wt} \%$ ) were determined. An increase in the solubility of both elements with the rise of $\mathrm{pH}$ value seems to be typical [40]. However, soluble material was not studied in detail, since the results indicate that the content of bioavailable elements is high.

\section{Conclusions}

1. The size of spherical aluminosilicate particles in the emitted PM varies within a broad range $(<1 \mu \mathrm{m}$ to ca $40 \mu \mathrm{m})$.

2. The chemical composition of the spherical particles also varies. Variability of the chemical composition of the aluminosilicate spheres is not related to their size. P- and Ca-rich particles also occur, but their content is significantly lower than the aluminosilicate ones.

3. Non-spherical aluminosilicate particles occur relatively rarely, but their size is larger than the spherical particles. Domains enriched in metals were noted on their surface. 
4. The char particles variable in morphology contain aluminosilicate spherical particles. Metal-rich domains were observed for some char particles.

5. The emitted PM contains other particles besides spherical and non-spherical aluminosilicate or char particles. Their size, morphology and chemical composition varies within a broad range. Particles rich in $\mathrm{Fe}, \mathrm{Cr}$ and $\mathrm{Ni}$ were noted relatively frequently.

6. The content of some elements in the bulk sample of emitted PM is relatively high. The values of enrichment factors calculated for the emitted material components in relation to average coal ash or the upper continental crust are very high for several elements.

7. Broad variation of the size and composition of the emitted PM indicates their differentiated environmental impact and possible dispersion over a large area, both close to the source and also in more distant areas. A detailed description of individual particles can be useful in modelling the dispersion of emitted PM.

8. Water-soluble, bioavailable fraction of the emitted $\mathrm{PM}$ is dominated by $\mathrm{S}, \mathrm{Ca}, \mathrm{K}, \mathrm{Mg}, \mathrm{Na}$, and $\mathrm{Cl}$. $\mathrm{Zn}$ and $\mathrm{Ni}$ also occur, but in low concentrations.

\section{Acknowledgements}

Our study was supported by Statutory Research of the Pedagogical University and Jagiellonian University. We thank Waldemar Obcowski for the final preparation of figures.

\section{Conflict of Interest}

The authors declare no conflict of interest.

\section{References}

1. Costs of air pollution from European industrial facilities 2008-2012 - an updated assessment. EEA Technical report No 20/2014, 2014.

2. Europe's Dark Cloud, How coal-burning countries are making their neighbours sick. Report published by WWF European Policy Office, Sandbag, CAN Europe, HEAL. Brussels, Belgium, 2016.

3. VASEV N. Governing energy while neglecting health The case of Poland. Health Policy, 121, 1147, 2017.

4. FENG Y., LI Y., CUI L. Critical review of condensable particulate matter. Fuel, 224, 801. 2018.

5. WANG G., DENG J., MA Z., HAO J., JIANG J. Characteristics of filterable and condensable particulate matter emitted from two waste incineration power plants in China. Science of the Total Environment, 639, 695, 2018.

6. Ochrona Środowiska. Główny Urząd Statystyczny, Informacje i Opracowania Statystyczne, Warszawa, 2016.
7. Energy Sector in Poland; Polish Information and Foreign Investment Agency, 2014.

8. Polska energetyka węglem stoi i długo się to nie zmieni, Polityka Surowcowa, 2, 4, 2018.

9. AHMARUZZAMAN M. A review on the utilization of fly ash. Progress in Energy and Combustion Science, 36, 327, 2010.

10. SUI Z., ZHANG Y., PENG Y., NORRIS P., CAO Y., PAN W.-P. Fine particulate matter emission and size distribution characteristics in an ultra-low emission power plant. Fuel, 185, 863, 2016.

11. WEINBERGER R., WEINER T., ANGERT A. Isotopic signature of atmospheric phosphate emitted from coal combustion. Atmospheric Environment, 136, 22, 2016.

12. LESTER E., ALVAREZ D., BORREGO A.G., VALENTIM B., FLORES D., CLIFT D.A., ROSENBERG P., KWIECINSKA B., BARRANCO R., PETERSEN H.I., MASTALERZ M., MILENKOVA K.S., PANAITESCU C., MARQUES M.M., THOMPSON A., WATTS D., HANSON S., PREDEANU G., MISZ M., WU T. The procedure used to develop a coal char classification Commission III Combustion Working Group of the International Committee for Coal and Organic Petrology. International Journal of Coal Geology, 81, 333, 2010.

13. WU H., WALL T., LIU G., \& BRYAN G. Ash Liberation from Included Minerals during Combustion of Pulverized Coal: The Relationship with Char Structure and Burnout. Energy \& Fuels, 13, 1197, 1999.

14. MISZ M., SMOŁKA-DANIELOWSKA D. The cooccurrence of inorganic and carbonaceous matter in fly ash samples from stoker boilers. Fuel Processing Technology, 77-78, 269, 2002.

15. CHEN Y., SHAH N., HUGGINS F. E., HUFFMAN G. O., DOZIER A. Characterization of ultrafine coal ash particles by energy-filtered TEM. Journal of Microscopy, 217, 225. 2004.

16. KNOX O.G.G., OGHORO C.O., BURNETT F.J., \& FOUNTAINE J.M. Biochar increases soil $\mathrm{pH}$, but is as ineffective as liming at controlling clubroot. Journal of Plant Pathology, 97 (1), 149, 2015.

17. POURRET O., HOUBEN D. Characterization of metal binding sites onto biochar using rare earth elements as a fingerprint. Heliyon, 4, e 00543, 2018.

18. GOODARZI F., HUGGINS F. E. Monitoring the species of arsenic, chromium and nickel in milled coal, bottom ash and fly ash from a pulverized coal-fired power plant in western Canada. Journal of Environmental Monitoring, 3, 1, 2001.

19. ŚWIETLIK R., TROJANOWSKA M., ŁOZYŃSKA M., MOLIK A. Impact of solid fuel combustion technology on valence speciation of chromium in fly ash. Fuel, 137, 306, 2014.

20. JIAO F., WIJAYA N., ZHANG L., NINOMIYA Y., HOCKING R. Synchrotron-Based XANES speciation of chromium in the oxy-fuel fly ash collected from labscale drop-tube furnace. Environmental Science and Technology, 45, 6640, 2011.

21. TORKMAHALLEH M. A., LIN L., HOLSEN T.M., RASMUSSEN D. H., HOPKE P. K. The impact of deliquescence and $\mathrm{pH}$ on $\mathrm{Cr}$ speciation in ambient $\mathrm{PM}$ Samples. Atmospheric Environment, 120, 427, 2012.

22. JALAVA P.I., WANG Q., KUUSPALO K., RUUSUNEN J., HAO L., FANG D., VÄISÄNEN O., RUUSKANEN A., SIPPULA O., HAPPO M.S., USKI O., KASURINEN S., TORVELA T., KOPONEN H., LEHTINEN K.E.J., KOMPPULA M., GU C., JOKINIEMI J., HIRVONEN 
R.-M. Day and night variation in chemical composition and toxicological responses of size segregated urban air PM samples in a high air pollution situation. Atmospheric Environment, 120, 427, 2015.

23. JABŁOŃSKA M., RIETMEIJER F., JANECZEK J. Finegrained barite in coal fly ash from the Upper Silesian Industrial Region. Environmental Geology, 40, 941, 2001.

24. PIO C., MIRANTE F., OLIVEIRA C., MATOS M., CASEIRO A., OLIVEIRA C., QUEROL X., ALVES C., MARTINS N., CERQUEIRA M., CAMÕES F., SILVA H., PLANA F. Size-segregated chemical composition of aerosol emissions in an urban road tunnel in Portugal. Atmospheric Environment, 71, 15, 2013.

25. Rozporządzenie Ministra Środowiska z dnia 5 września 2016 r. w sprawie sposobu prowadzenia oceny powierzchni ziemi. Załącznik nr 1, Dz. U., Poz. 1395, 2016.

26. WILCZYŃSKA-MICHALIK W., MORYL R., SOBCZYK J., MICHALIK M., 2014. Composition of coal combustion by-products: the importance of combustion technology. Fuel Processing Technology, 124, 35, 2014.

27. GOODARZI F., SANEI H. Plerosphere and its role in reduction of emitted fine fly ash particles from pulverized coal-fired power plants. Fuel, 88, 382, 2009.

28. MORENO N., QUEROL X., ANDRÉS J. M., STANTON K., TOWLER M., NUGTEREN H., JANSSENJURKOVICOVÁ M., JONESE R. Physico-chemical characteristics of European pulverized coal combustion fly ashes. Fuel, 84, 1351, 2005.

29. GAO L., WANGA Y., HUANGA Q., GUOB S. Emission of mercury from six low calorific value coal-fired power plants. Fuel, 210, 611, 2017.

30. KOMOSIŃSKI B., RACHWAŁ T., PAŁAMARCZUK P., MATHEWS B., TALIK E., PASTUSZKA J., STEC K., BILIŃSKI W., KONIECZYŃSKI J. Wyniki pomiarów, analiz i badań oraz omówienie wyników. In Właściwości pyłu respirabilnego emitowanego z wybranych instalacji, Ed. J. Konieczyński, 87, 2010.

31. BLISSETT R.S., SMALLEY N., ROWSON N.A. An investigation into six coal fly ashes from the United Kingdom and Poland to evaluate rare earth element content. Fuel, 119, 236, 2014.
32. FRANUS W., WIATROS-MOTYKA M.M., WDOWIN M., 2015. Coal fly ash as a resource for rare earth elements. Environmental Science and Pollution Research, 2 (12), 9464, 2015.

33. ADAMCZYK Z., KOMOREK J., LEWANDOWSKA M., NOWAK J., BIAŁECKA B., CAŁUSZ-MOSZKO J., KLUPA A., 2018. Ashes from bituminous coal burning in fluidized bed boilers as a potential source of rare earth elements. Gospodarka Surowcami Mineralnymi - Mineral Resources Management, 34 (2), 21, 2018.

34. KETRIS M.P., YUDOVICH YA. E. Estimations of Clarkes for Carbonaceous biolithes: World averages for trace element contents in black shales and coals. International Journal of Coal Geology, 78, 135, 2009.

35. RUDNICK R.L., GAO S. The composition of the continental crust. In Treatise on Geochemistry - The Crust. Eds Rudnick R. L., Holland H. D., \& Turekian K. K., Elsevier, Oxford, 1, 2003.

36. REIMANN C., FLEM B., FABIAN C., BIRKE M., LADENBERGER A., NEGREL P., DEMETRIADES A., HOOGEWERFF J., \& THE GEMAS PROJECT TEAM. Lead and lead isotopes in agricultural soils of Europe The continental perspective. Applied Geochemistry, 27, 532, 2012.

37. MAHOWALD N., ALBANI S., KOK J.F., ENGELSTAEDER S., SCANZA R., WARD D. S., FLANNER M.G. The size distribution of desert dust aerosols and its impact on the Earth System. Aeolian Research, 15, 53, 2014.

38. van der DOES M., KORTE1 L.F., MUNDAY C.I., BRUMMER G.-J. A., STUUT J.-B. W. Particle size traces modern Saharan dust transport and deposition across the equatorial North Atlantic. Atmospheric Chemistry and Physics, 16 (21), 13697, 2016.

39. FISHMAN N.S., RICE C.A., BREIT G.N., JOHNSON R.D. Sulfur-bearing coatings on fly ash from a coal-fired power plant: composition, origin, and influence on ash alteration. Fuel, 78, 187, 1999.

40. IZQUIERDO M., QUEROL X. Leaching behaviour of elements from coal combustion fly ash: An overview. International Journal of Coal Geology, 94 54, 2012. 